QUARTERLY TECHNICAL PROGRESS REPORT

FOR THE PERIOD ENDING JUNE 30, 2002

\title{
TITLE: FIELD DEMONSTRATION OF CARBON DIOXIDE MISCIBLE FLOODING IN THE LANSING-KANSAS CITY FORMATION, CENTRAL KANSAS
}

DOE Contract No. DE-AC26-00BC15124

Contractor: $\quad$ University of Kansas Center for Research, Inc. 2385 Irving Hill Road

Lawrence, KS 66044

DOE Program: $\quad$ Class II Revisited - Field Demonstrations

Award Date: $\quad$ March 8, 2000

Total Project Budget: $\quad \$ 5,388,683$

DOE Cost Amount: $\quad \$ 1,892,094$

Program Period: $\quad$ March 8, 2000 - March 8, 2006 (BP1 03/00-06/01, BP2 06/0103/05, BP3 03/05-03/06)

Reporting Period: $\quad$ April 1, 2002 - June 30, 2002

DOE Project Manager: $\quad$ Daniel J. Ferguson, NPTO Tulsa, Oklahoma

Contractor Contact: $\quad$ Alan P. Byrnes

Kansas Geological Survey

1930 Constant Ave., Lawrence, Kansas 66047

email: abyrnes@kgs.ukans.edu

phone: 785-864-2177

Principal Investigators: $\quad$ Alan Byrnes (Program Manager Budget Period 1)

G. Paul Willhite (Program Manager Budget Periods 2\&3)

Don Green, Martin Dubois, Richard Pancake, Timothy Carr, W. Lynn Watney, John Doveton, Willard Guy, Rodney Reynolds, Rajesh Kunjithaya, Dave Murfin, James Daniels, Niall Avison, Russell Martin, William Flanders, Dave Vander Griend, Eric Mork, Paul Cantrell 


\section{DISCLAIMER:}

This report was prepared as an account of work sponsored by an agency of the United States Government. Neither the United States Government nor any agency thereof, nor any of their employees, makes any warranty, express or implied, or assumes any legal liability or responsibility for the accuracy, completeness, or usefulness of any information, apparatus, product, or process disclosed, or represents that its use would not infringe privately owned rights. Reference herein to any specific commercial product, process, or service by trade name, trademark, manufacturer, or otherwise does not necessarily constitute or imply its endorsement, recommendation, or favoring by the United States Government or any agency thereof. The views and opinions of authors herein do not necessarily state or reflect those of the United States Government or any agency thereof.

\section{ABSTRACT:}

Progress is reported for the period from July 1, 2002 to September 30, 2002. Assessment of the demonstration site has defined many aspects of the reservoir. Technical design and budget for a larger (60-acre, $24.3 \mathrm{ha}$ ) $\mathrm{CO}_{2}$ demonstration project are being reviewed by the US DOE for approval. Further analysis of the pilot site by the partners has indicated that a staged demonstration is considered optimal. A phased approach to implementation of the demonstration is proposed to reduce the risk of uncertainties as to whether the reservoir has basic properties (connectivity and ability to pressure-up) conducive to a meaningful $\mathrm{CO} 2$ flood demonstration. The proposed plan is to flood a 10+-acre pattern. The results of this small flood will be used to evaluate the viability of performing a larger-scale ( $\sim 60$-acre) demonstration and will be used by the partners to decide their role in a larger-scale demonstration. The 10+-acre pattern requires the least up-front expense to all parties to obtain the data required to accurately assess the viability and economics of $\mathrm{CO} 2$ flooding in the $\mathrm{L}-\mathrm{KC}$ and of a larger-scale demonstration.

In general, the following significant modifications to the original Statement of Work are proposed:

1. The proposed plan would extend the period of Budget Period 1 to May 7, 2003.

2. Redefine the period of Budget Period 2 from 3/7/01-3/7/05 to 5/7/03-3/7/08.

3. Redefine the period of Budget Period 3 from 3/7/05-3/7/06 to 3/7/08-3/7/09.

4. To allow initial verification of the viability of the process before proceeding into the flood demonstration, move activities involved with preparing wells in the flood pattern (Task 5.1), repressurizing the pattern (Task 5.2), and constructing surface facilities (Task 5.3) from Budget Period 2 to Budget Period 1

5. Allow US Energy Partners (USEP) to be a supplier of carbon dioxide from the ethanol plant in Russell, Kansas

6. Change the pilot flood pattern, including the number and location of wells involved in the pilot.

7. Expenses are shifted from Budget Period 2 to Budget Period 1 to cover costs of additional reservoir characterization. All modified activities and tasks would maintain the existing required industry match of 55\% in Budget Period 1, 65\% in Budget Period 2, and 90\% in Budget Period 3. Carbon dioxide supplied by the USEP ethanol facility would be valued 
such that the total cost of $\mathrm{CO} 2$ delivered to the demonstration site injection wellhead would not exceed the $\$ 3.00 / \mathrm{MCF}$ cost of supplying $\mathrm{CO} 2$ from Guymon, OK. Total cost of the modified project is $\$ 4,415,300$ compared with $\$ 5,388,064$ in the original project. The modified project would require no additional funding from US DOE. 


\section{TABLE OF CONTENTS}

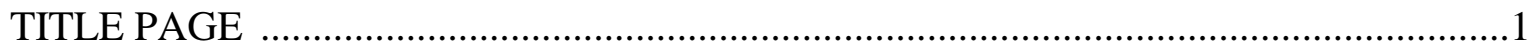

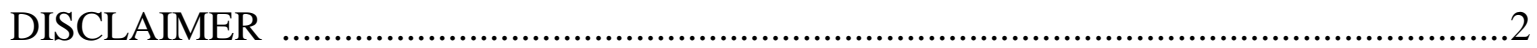

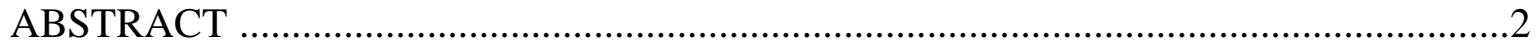

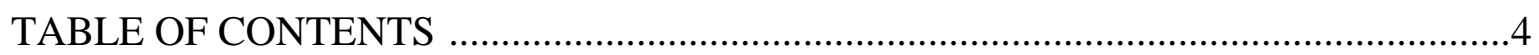

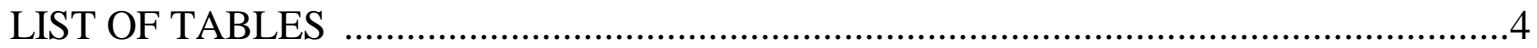

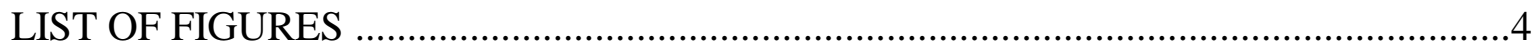

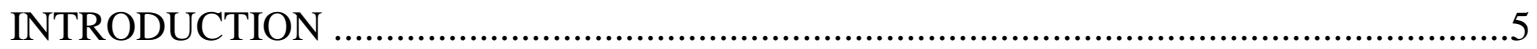

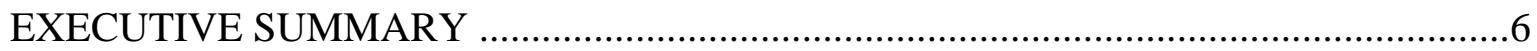

RESULTS AND DISCUSSION ........................................................................6

TASK 3.2 ECONOMIC AND RECOVERY ANALYSIS OF PILOT …......................6

TASK 7.0 PROJECT MANAGEMENT ................................................................ 11

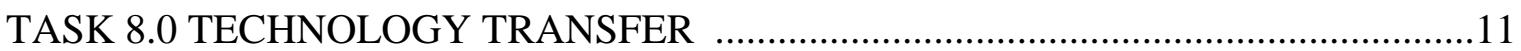

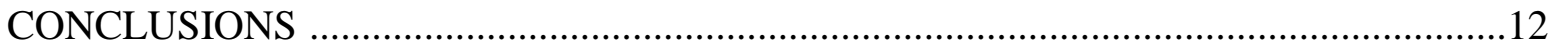

\section{LIST OF TABLES}

Table 1. Budget Summary for Revised Kansas $\mathrm{CO}_{2}$ Project ............................................9

Table 2. Milestone Plan for Revised Project ............................................................... 10

\section{LIST OF FIGURES}

Figure 1. Proposed 10+-acre Pilot Pattern ................................................................8

Figure 2. Comparison of Predicted Oil Recovery for $10+$ acre Pilot ................................ 8 


\section{INTRODUCTION}

Objectives - The objective of this Class II Revisited project is to demonstrate the viability of carbon dioxide miscible flooding in the Lansing-Kansas City formation on the Central Kansas Uplift and to obtain data concerning reservoir properties, flood performance, and operating costs and methods to aid operators in future floods. The project addresses the producibility problem that these Class II shallow-shelf carbonate reservoirs have been depleted by effective waterflooding leaving significant trapped oil reserves. The objective is to be addressed by performing a $\mathrm{CO}_{2}$ miscible flood in a 10-acre ( $4.05 \mathrm{ha}$ ) pilot in a representative oomoldic limestone reservoir in the Hall-Gurney Field, Russell County, Kansas. At the demonstration site, the Kansas team will characterize the reservoir geologic and engineering properties, model the flood using reservoir simulation, design and construct facilities and remediate existing wells, implement the planned flood, and monitor the flood process. The results of this project will be disseminated through various technology transfer activities.

\section{Project Task Overview -}

Activities in Budget Period 1 (03/00-05/03) involve reservoir characterization, modeling, and assessment:

- Task 1.1- Acquisition and consolidation of data into a web-based accessible database

- Task 1.2 - Geologic, petrophysical, and engineering reservoir characterization at the proposed demonstration site to understand the reservoir system

- Task 1.3 - Develop descriptive and numerical models of the reservoir

- Task 1.4 - Multiphase numerical flow simulation of oil recovery and prediction of the optimum location for a new injector well based on the numerical reservoir model

- Task 2.1 - Drilling, sponge coring, logging and testing a new CO2 injection well to obtain better reservoir data

- Task 2.2 - Measurement of residual oil and advanced rock properties for improved reservoir characterization and to address decisions concerning the resource base

- Task 3.1 - Advanced flow simulation based on the data provided by the improved characterization

- Task 3.2 - Assessment of the condition of existing wellbores, and evaluation of the economics of carbon dioxide flooding based on the improved reservoir characterization, advanced flow simulation, and engineering analyses

- Task 4.1 - Review of Budget Period 1 activities and assessment of flood implementation

Activities in Budget Period 2 (05/03-03/08) involve implementation and monitoring of the flood:

- Task 5.1 - Remediate all wells in the flood pattern

- Task 5.2 - Re-pressure the pilot area by water injection

- Task 5.3 - Construct surface facilities

- Task 5.4 - Implement $\mathrm{CO}_{2}$ flood operations

- Task 5.5 - Analyze $\mathrm{CO}_{2}$ flooding progress - carbon dioxide injection will be terminated at the end of Budget Period 2 and the project will be converted to continuous water injection.

Activities in Budget Period 3 (03/08-03/09) will involve post-CO2 flood monitoring:

- Task 6.1 - Collection and analysis of post-CO2 production and injection data

Activities that occur over all budget periods include:

- Task 7.0 - Management of geologic, engineering, and operations activities

- Task 8.0 - Technology transfer and fulfillment of reporting requirements 


\section{EXECUTIVE SUMMARY:}

Progress is reported for the period from April 1, 2002 to June 30, 2002. Assessment of the demonstration site has defined many aspects of the reservoir. Technical design and budget for a larger (60-acre, $24.3 \mathrm{ha}$ ) $\mathrm{CO}_{2}$ demonstration project are being reviewed by the US DOE for approval. Further analysis of the pilot site by the partners has indicated that a staged demonstration is considered optimal. A phased approach to implementation of the demonstration is proposed to reduce the risk of uncertainties as to whether the reservoir has basic properties (connectivity and ability to pressure-up) conducive to a meaningful $\mathrm{CO} 2$ flood demonstration. The proposed plan is to flood a 10+-acre pattern. The results of this small flood will be used to evaluate the viability of performing a larger-scale ( 60 -acre) demonstration and will be used by the partners to decide their role in a larger-scale demonstration. The 10+-acre pattern requires the least up-front expense to all parties to obtain the data required to accurately assess the viability and economics of $\mathrm{CO} 2$ flooding in the $\mathrm{L}-\mathrm{KC}$ and of a larger-scale demonstration.

In general, the following significant modifications to the original Statement of Work are proposed:

8. The proposed plan would extend the period of Budget Period 1 to May 7, 2003.

9. Redefine the period of Budget Period 2 from 3/7/01-3/7/05 to 5/7/03-3/7/08.

10. Redefine the period of Budget Period 3 from 3/7/05-3/7/06 to 3/7/08-3/7/09.

11. To allow initial verification of the viability of the process before proceeding into the flood demonstration, move activities involved with preparing wells in the flood pattern (Task 5.1), repressurizing the pattern (Task 5.2), and constructing surface facilities (Task 5.3) from Budget Period 2 to Budget Period 1

12. Allow US Energy Partners (USEP) to be a supplier of carbon dioxide from the ethanol plant in Russell, Kansas

13. Change the pilot flood pattern, including the number and location of wells involved in the pilot.

14. Expenses are shifted from Budget Period 2 to Budget Period 1 to cover costs of additional reservoir characterization. All modified activities and tasks would maintain the existing required industry match of 55\% in Budget Period 1, 65\% in Budget Period 2, and 90\% in Budget Period 3. Carbon dioxide supplied by the USEP ethanol facility would be valued such that the total cost of $\mathrm{CO} 2$ delivered to the demonstration site injection wellhead would not exceed the $\$ 3.00 / \mathrm{MCF}$ cost of supplying $\mathrm{CO} 2$ from Guymon, OK. Total cost of the modified project is $\$ 4,415,300$ compared with $\$ 5,388,064$ in the original project. The modified project would require no additional funding from US DOE.

\section{RESULTS AND DISCUSSION:}

\section{TASK 3.2 ECONOMIC AND RECOVERY ANALYSIS OF PILOT}

The 10+-acre flood pattern is shown in Figure 1. Minimum predicted recovery ranges down to $22,300 \mathrm{BO}$ assuming Sorw is $30 \%$ in all layers. Maximum recovery reaches as high as 47,000 BO assuming Sorw is $40 \%$ in some layers as predicted by VIP simulations. Transpetco Eng./Kinder-Morgan predicted recoveries are approximately 27,000-28,000 BO based on 
displacement calculations and fractional pattern modeling (Figure 2). Recovery in the economic models is cut-off after the first year the flood exhibits negative cash flow.

Based on present understanding of permeability in the region of the Carter-Colliver \#1 Co2 I well injectivity is modeled to be limited to $100-200 \mathrm{RB} / \mathrm{D}$. Figure 2 illustrates oil production for the various models.

Oil recovery estimates are strongly influenced by:

1. Sorw

2. Vertical distribution of horizontal permeability (permeability differences between upper, middle, and lower $\mathrm{C}$ flood cycles)

3. More lateral distribution of permeability

4. Presence or absence of vertical permeability barriers (flood cycle bounding bioclastic-rich layers)

5. Gravity override of $\mathrm{CO} 2$. Density ratio $\mathrm{CO} 2 / \mathrm{oil}=0.6-0.8$ (varying with pressure and oil density) - most $\mathrm{CO} 2$ projects have ratio of 0.9 . Gravity is not a problem in most projects but is here.

$\mathrm{CO} 2$ is presently being predicted to stay within the high permeability upper flood cycle and preferentially sweep this layer and not efficiently sweep the middle flood cycle or, if it is injected in the middle flood cycle may quickly migrate from the middle flood cycle up to the upper cycle again only sweeping the upper flood cycle efficiently.

Favorable mobility ratio $(\mathrm{M} \sim 2)$ and gravity working for downward migration may have acted to improve the waterflood sweep efficiency in the middle flood cycle. Significantly, lower mobility ratio for $\mathrm{CO} 2(\mathrm{M}=24$, most project have $\mathrm{M}=10-15)$ would act to decrease $\mathrm{CO} 2$ sweep in lowerpermeability middle flood cycle.

Several factors may provide higher recoveries than predicted:

1. Preferential stimulation and initial injection in the middle flood cycle may provide improved processing of the middle flood cycle and could provide additional recovery of up to $\sim 20 \%$.

2. If the reservoir exhibits the permeability layering as modeled, careful tuning of the WAG cycle to the specific reservoir permeability architecture in the Colliver lease could improve the sweep in lower permeability intervals. Tuned WAG cycles have improved recovery up to $30 \%$ in commercial floods- it could be guessed that using a tuned WAG cycle might produce an additional $20 \%$ recovery.

3. If each of the high side potential effects is only $50 \%$ effective, additional potential recovery could be up to $20 \%$.

4. Other high-side parameters for which estimation of influence on improved recovery is difficult include the possible presence of vertical permeability barriers (allowing isolated processing of the middle flood cycle), and the role of small-scale bedding architecture such as cross-bedding or stylolites that would act to limit gravity override.

5. There are many unknowns concerning lateral heterogeneity within the flood cycles such as shingling, weathering, and other diagenetic processes that might result in minimizing 
gravity override and promote more uniform sweep efficiency.

Several factors may provide lower recoveries than predicted:

Low-side potential is predominantly influenced by uncertainty in Sorw. Data on Sorw for high permeability rocks indicates these rocks can have both a high Sorw (45\%) and a low Sorw $(\sim 20 \%)$ depending on initial oil saturation and pore architecture. Wireline logs indicate saturations are approximately $37 \%$ but the Archie cementation and saturation exponent log parameters ( $m$ and $n$ ) in these oomoldic limestones are significantly different than the conventional $\mathrm{m}$ and $\mathrm{n}$ values of 2 and 2 , respectively, and could vary from those measured on the core obtained.

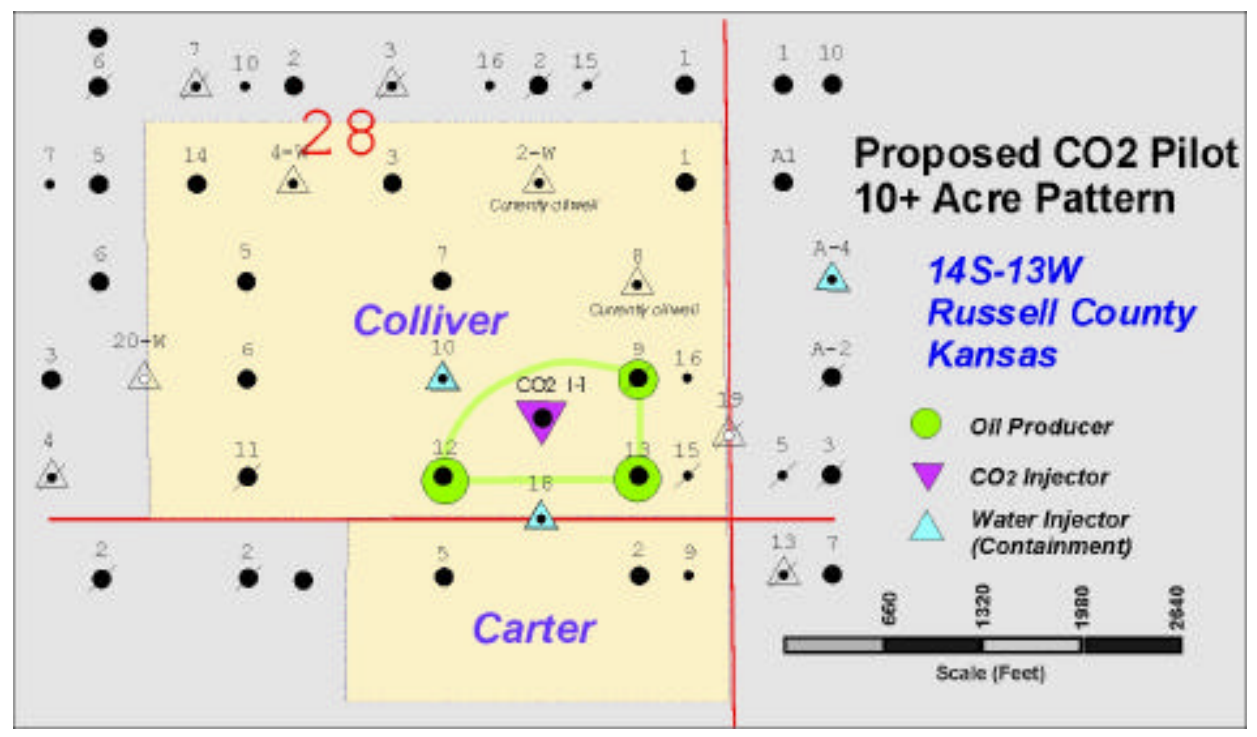

Figure 1. Proposed $10+$ acre pilot with WAG injection in CO2\#1, water injection in \#10 and $\# 18$, and production from \#9, \#12, and $\# 13$.

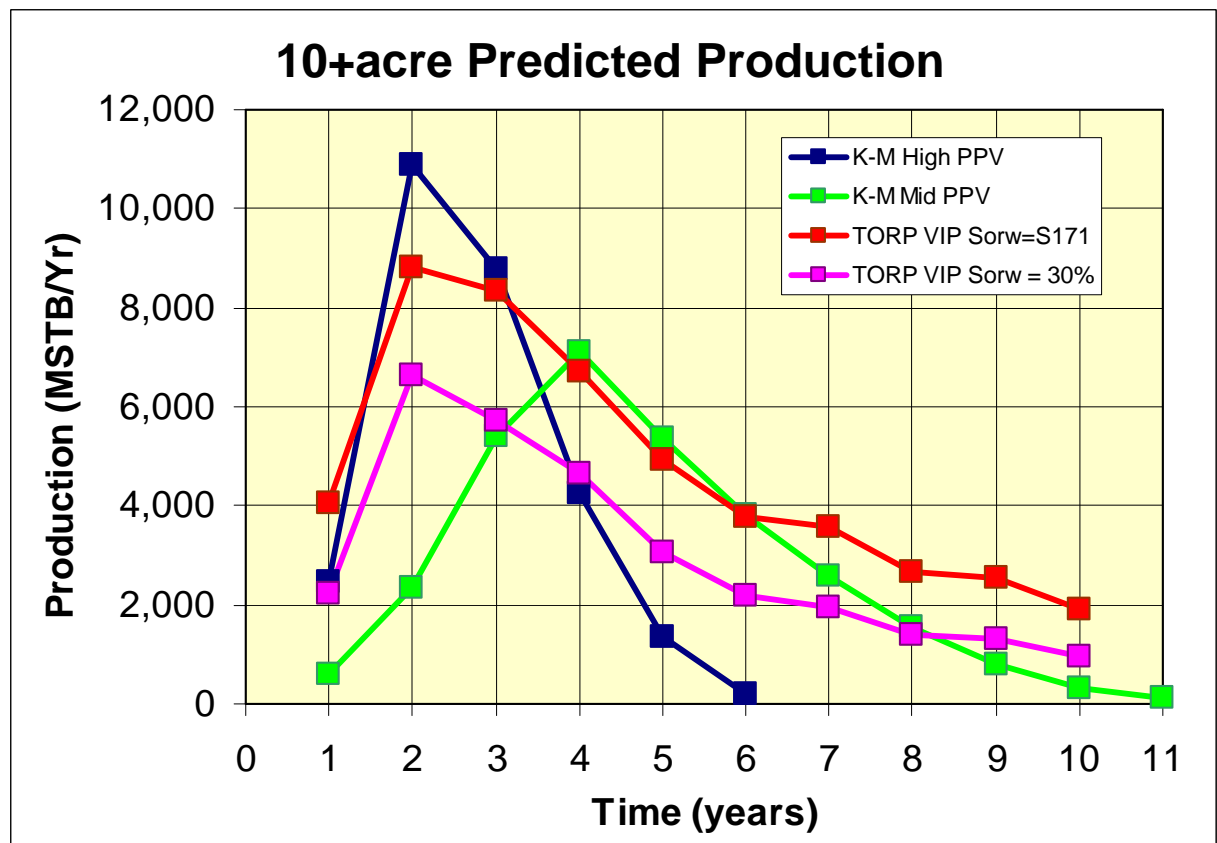

Figure 2.

Comparison of predicted oil recovery for $10+$ acre pilot for various models. 
A general summary of the revised budget compared to the original project budget is shown in Table1. The revised list of tasks and milestone schedule is presented in Table 2.

TABLE 1. General Budget Summary for Revised Kansas CO2 Flood Project

\begin{tabular}{|c|c|c|}
\hline & Original Project & Modified Project \\
\hline Flood Performance & & \\
\hline Acres & 40 & $10+$ \\
\hline Total CO2 Injected (mcf) & 843,000 & 290,000 \\
\hline WAG Years & 3.7 & 6 \\
\hline Post CO2 WF years (DOE) & & 1 \\
\hline Oil Produced (Commercial Life) & 75,300 & 28,000 \\
\hline Facilities & & \\
\hline Drill \& Equip \#1 CO2 I (Task 2.1) & $\$ 236,180$ & $\$ 341,750$ \\
\hline Rework and upgrade wells (old Task 5.1/Task 2.3) & $\$ 474,500$ & $\$ 259,197$ \\
\hline Surface facilities (Task 2.3.5) & $\$ 322,575$ & $\$ 282,293$ \\
\hline Drill and Equip Water Supply Well (Task 2.3.1) & $\$ 35,000$ & $\$ 35,000$ \\
\hline Flood Operations & $\$ 1,068,255$ & $\$ 918,239$ \\
\hline Repressure Reservoir (Task 2.3.4) & $\$ 16,377$ & $\$ 50,576$ \\
\hline Well \& Pattern Testing (Task 2.3) & $\$ 0$ & $\$ 180,576$ \\
\hline CO2 Slug, WAG + Admin (Task 5.4) & $\$ 734,231$ & $\$ 605,691$ \\
\hline Post waterflood (Task 5.4) & $\$ 100,858$ & $\$ 91,818$ \\
\hline CO2 Supply $\quad$ Subtotal & $\$ 851,466$ & $\$ 928,661$ \\
\hline Value of $\mathrm{CO} 2$ contributed & $\$ 1,608,900$ & $\$ 870,000$ \\
\hline Recycled CO2 & $\$ 414,045$ & $\$ 0$ \\
\hline Research, Data, Tech Transfer, Admin. & $\$ 2,022,945$ & $\$ 870,000$ \\
\hline $\begin{array}{l}\text { KU Research, Data Collection \& Tech Transfer } \\
\text { Outside Consulting \& Adm. }\end{array}$ & $\begin{array}{r}\$ 1,446,018 \\
0\end{array}$ & $\begin{array}{r}\$ 1,633,003 \\
\$ 65,397\end{array}$ \\
\hline Subtotal & $\$ 1,446,018$ & $\$ 1,698,400$ \\
\hline PROJECT TOTAL EXPENSES & $\$ 5,388,684$ & $\$ 4,415,300$ \\
\hline Revenue Sources & & \\
\hline$\overline{\mathrm{DOE}(\$ F a c \text { \$LOE) }}$ & $\$ 676,261$ & $\$ 766,469$ \\
\hline $\mathrm{DOE}(\$ \mathrm{CO} 2)$ & $\$ 708,031$ & $\$ 304,500$ \\
\hline DOE (Research, Data, Tech Transfer) & $\$ 507,802$ & $\$ 631,343$ \\
\hline Murfin (\$Cap \$LOE) & $\$ 830,259$ & $\$ 903,112$ \\
\hline Kinder-Morgan In-kind CO2 & $\$ 268,150$ & $\$ 188,500$ \\
\hline Kinder-Morgan Cash & $\$ 1,359,858$ & $\$ 54,716$ \\
\hline USEP In-kind CO2 & $\$ 0$ & $\$ 377,000$ \\
\hline KUCR In-kind & $\$ 938,323$ & $\$ 1,001,660$ \\
\hline State Of KS DOC & $\$ 100,000$ & $\$ 188,000$ \\
\hline PROJECT TOTAL REVENUES & $\$ 5,388,684$ & $\$ 4,415,300$ \\
\hline DOE Total & $\$ 1,892,094$ & $\$ 1,702,312$ \\
\hline DOE Difference from Original Project & $\$ 0$ & $-\$ 189,782$ \\
\hline
\end{tabular}

DE-AC26-00BC15124

Quarterly Technical Progress Report June 30, 2002 


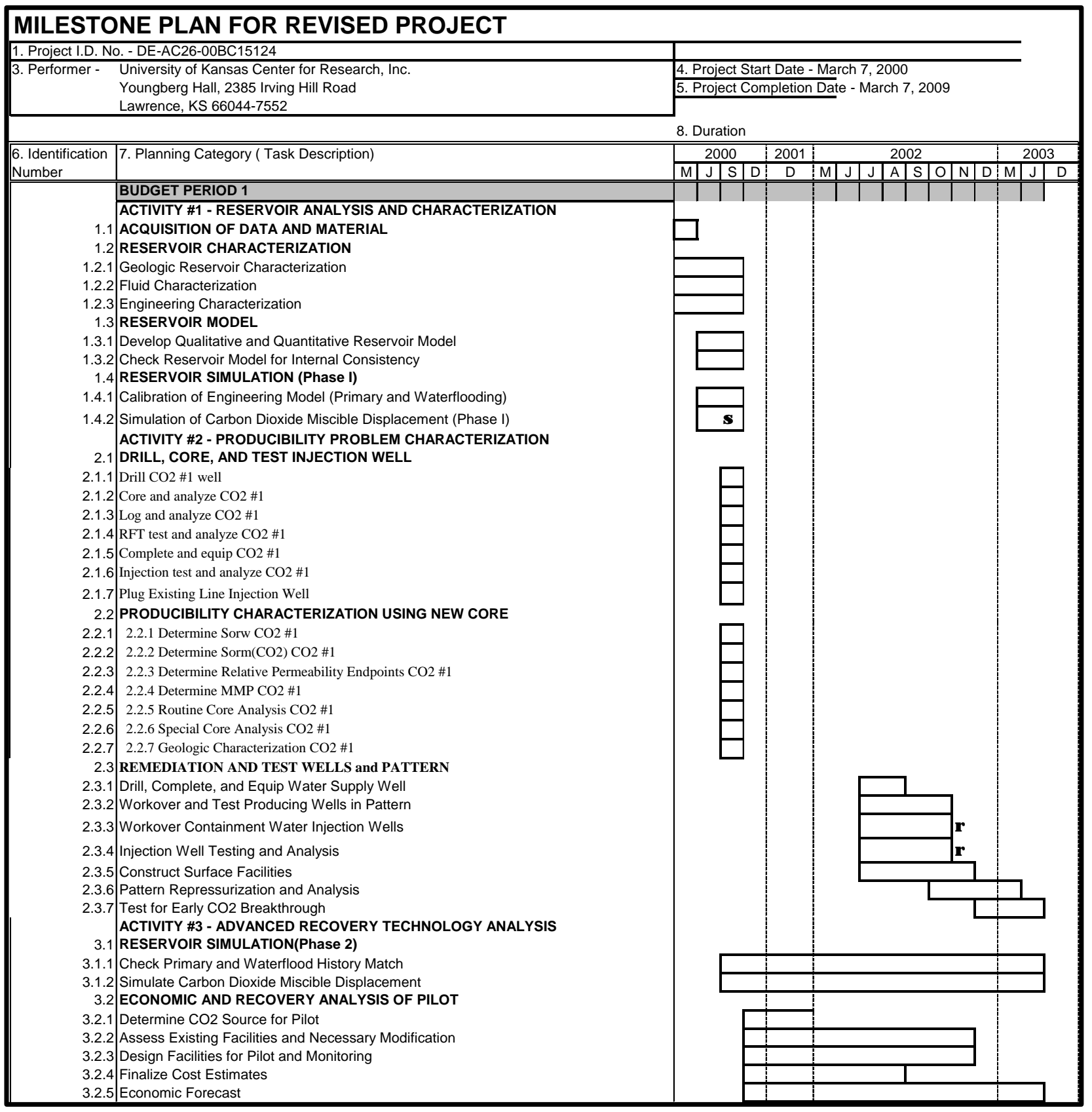




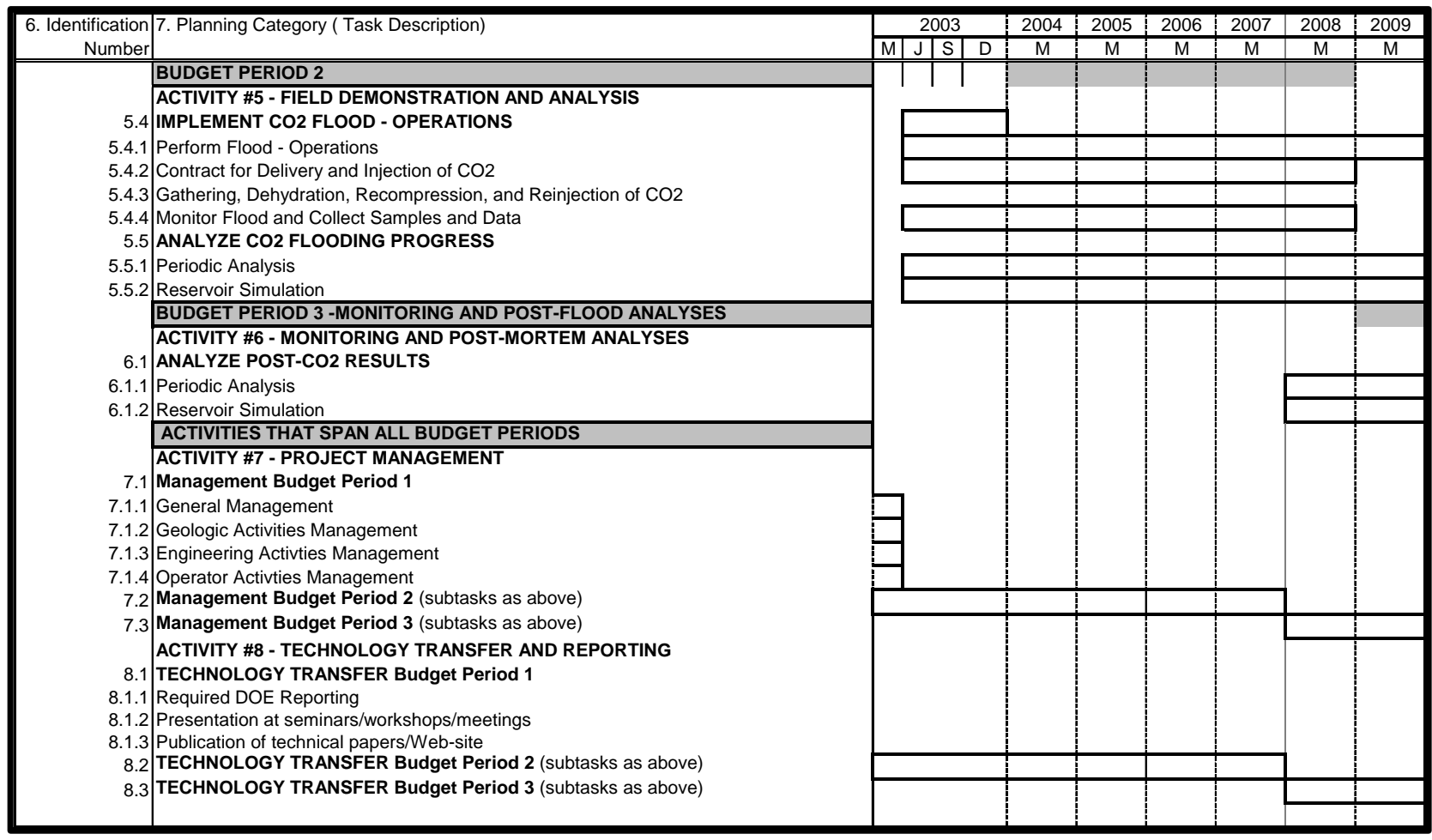

\section{TASK 7.0 PROJECT MANAGEMENT}

A meeting was held on April 16, 2002 in Tulsa, OK the following personnel were present: TORP) Paul Willhite; KGS) Alan Byrnes; DOE) William Lawson, Dexter Sutterfield. Topics covered included: economics of various patterns and the possibility of modifying the pilot to $10+$ acres, project shortfalls, CO2 sequestration aspects of the project. It was agreed that a proposal to modify the existing project and do a 10+acre pilot could be submitted and would be reviewed.

David Murfin, of Murfin Drilling Company, and Michael Vess, of Vess Oil Company, met at the office of Vess Oil Company in Wichita, KS on April 26, 2002. Murfin Drilling Company proposed to MV Energy LLP (a partnership of Murfin Drilling, Vess Oil, and GE Capital) the purchase of the portion of the Colliver lease that is involved with the $\mathrm{CO} 2$ pilot. This proposal and the possible value of the lease are being evaluated by MV Energy and GE Capital.

Following analysis in the first quarter and in the beginning of the second quarter and various technical meetings in April and May, a revised plan for the project was finalized and submitted to the DOE on May 30, 2002.

\section{TASK 8.0 TECHNOLOGY TRANSFER}

A paper was presented at the Society of Petroleum Engineers/Department of Energy Thirteenth Symposium on Improved Oil Recovery, April 13-17, 2002, in Tulsa, Oklahoma: SPE Paper \#75178, “Cost Reduction and Injectivity Improvements for CO2 Foams for Mobility Control”, 
R.B. Grigg, New Mexico Petroleum Recovery Research Center; J. Tsau, University of Kansas; F.D. Martin, Dave Martin \& Assocs.

\section{CONCLUSIONS}

Uncertainty in reservoir permeability distribution and residual oil saturation is sufficiently great that assuring viability of the project warrants modification of the pilot design to perform an initial $10+$ acre pilot. A modified plan has been developed and submitted to DOE for approval. Expenses are shifted from Budget Period 2 to Budget Period 1 to cover costs of additional reservoir characterization. All modified activities and tasks would maintain the existing required industry match of 55\% in Budget Period 1, 65\% in Budget Period 2, and 90\% in Budget Period 3. Carbon dioxide supplied by the USEP ethanol facility would be valued such that the total cost of $\mathrm{CO} 2$ delivered to the demonstration site injection wellhead would not exceed the $\$ 3.00 / \mathrm{MCF}$ cost of supplying CO2 from Guymon, OK. Total cost of the modified project is $\$ 4,415,300$ compared with $\$ 5,388,064$ in the original project. The modified project would require no additional funding from US DOE. Based on current knowledge of the reservoir, the modified project will provide the needed additional reservoir data and an economically viable plan for implementation of the demonstration project. 